\title{
DESMUNDO: UMA EXPERIÊNCIA DE EXÍLIO E (RE)CONSTRUÇÃO IDENTITÁRIA
}

\author{
leda Maria Sorgi Pinhaz Elias (UEM) \\ Cíntia Roberto Marson (UEM)
}

Resumo: $O$ presente trabalho tem o intuito de analisar de que forma se estabelecem o exílio, a exiliência e a (re)construção identitária em Desmundo (1996), obra de Ana Miranda. O romance propõe uma nova visão sobre a história do início da colonização no Brasil. A protagonista da narrativa, Oribela, uma órfã portuguesa, é enviada à colônia, junto a mais seis meninas, incumbidas de se casarem com os colonos desbravadores do novo mundo. A jovem é uma imigrante insatisfeita com o seu deslocamento da Europa para a América Latina e com o destino predeterminado para sua vida, em um espaço desconhecido, que se configura como um desmundo. Oribela é uma das personagens da obra que vivencia o exílio, experiência que lhe oprime, mas que ao mesmo tempo lhe impulsiona a lutar por seus ideais. Por meio das situações vividas e das relações interpessoais que a personagem desenvolve ao longo da narrativa, Oribela tem a chance de (re)construir a sua identidade, que se encontra fragmentada devido ao desenraizamento espacial e cultural. Assim, as experiências se tornam significativas para que a órfã encontre, novamente, a si mesma. Perante o exposto, este trabalho tem como principal suporte teórico, crítico e analítico os estudos de Edward Said (2001), Alexis Nouss (2016), Zygmunt Bauman (2005) e Stuart Hall (2006).

Palavras-chave: Exílio; Exiliência; Identidade; Desmundo.

Abstract: The present work aims to analyze the way exile, the feeling of being exiled (even if you are not) and identity (re)construction are established in Desmundo (1996), Ana Miranda's work. The novel is a new view about the history of early period of Brazil colonization. The narrative protagonist, Oribela, a Portuguese orphan, is sent to the colony, along with six other girls, assigned to marry the pathfinder settlers of the new world. The young woman is an immigrant, who is dissatisfied with her move from Europe to Latin America and with the predetermined destiny for her life, in an unknown space, that is configured as a non-world (desmundo). Oribela is one of the characters 
who experience exile, an experience that oppresses her, but at the same time pushes her to fight for her ideals. Through the lived situations and interpersonal relationships that the character develops throughout the narrative, Oribela has the chance to (re)build her identity, which is fragmented due to spatial and cultural uprooting. Thus, the experiences become meaningful for the orphan to find herself again. In view of the foregoing, this work has the studies by Edward Said (2001), Alexis Nouss (2016), Zygmunt Bauman (2005) and Stuart Hall (2006) as the main theoretical, critical and analytical support.

Keywords: Exile; Exile feelings; Identity; Desmundo.

\section{INTRODUÇÃO}

Em Desmundo (1996), Ana Miranda busca reescrever a história da colonização do Brasil com criatividade, utilizando uma linguagem elaborada, dotada de um brasilianismo intenso, além de dar voz à mulher, silenciada num sistema predominantemente patriarcal e machista. Dessa forma, subverte o padrão histórico, no qual o discurso narrativo é majoritariamente masculino. A obra é considerada metaficção historiográfica, uma vez que remete a eventos e personagens históricos, permitindo que vislumbremos no texto, o entrelaçamento entre ficção e história.

Como o romance aborda o período da colonização, deparamo-nos com a história da vinda de muitos portugueses para o Brasil. Na história oficial, a figura marcante é a do homem, desbravador, enquanto a participação das mulheres no cenário de colonização recebe quase que nenhum 
registro. No entanto, é sabido que elas também participaram desse processo, e que sem elas não se formaria a nação brasileira. A partir de um documento histórico que comprova a solicitação ao rei de Portugal de mulheres para o Brasil, Ana Miranda utiliza a ficção para dar vez e voz a essa mulher silenciada durante vários séculos. Por meio do discurso de Oribela, acompanhamos o primeiro contato com a terra, as frustrações, a garra e conflitos internos vividos por uma jovem, que chega ao Brasil em meados do século XVI.

Perante o exposto, este trabalho divide-se em três seções: na primeira, apresentamos os estudos de Said (2003) e Nouss (2016), no que tange ao modo como o exílio e a exiliência se configuram diante de situações específicas, além das concepções de identidade, de acordo com Bauman (2005) e Hall (2006), e do conceito de subjetivação feminina, segundo Touraine (2007). Na segunda seção, sob o respaldo teórico citado, analisamos de que forma se estabelecem o exílio, a exiliência e a (re)construção identitária em Desmundo (1996), romance de Ana Miranda. Por fim, na terceira seção, retomamos brevemente o que foi discutido ao longo da análise e apresentamos as considerações finais deste trabalho. 


\section{EXÍLIO: A NECESSIDADE DE (RE)CONSTRUÇÃO IDENTITÁRIA}

A questão da emigração é assunto recorrente na literatura de países que sofreram o processo de colonização, tanto no passado quanto nos dias atuais, recontada no mundo, por diversas vozes. No que tange à ficção brasileira contemporânea feminina, Zolin (2018) afirma que esta é frequentemente marcada por processos de deslocamentos: exílio, migração, errâncias, representados enquanto estratégia de subjetificação dos indivíduos no contexto pósmoderno. Assim,

Ao retratar experiências exílicas de mulheres em contextos tão disfóricos e/ou representálas em situações de deslocamentos diversos, esses romances fazem avultar, cada um a seu modo, figuras femininas empenhadas em processos de reterritorialização e na (re) construção de suas identidades, num longo, lento e árduo processo de subjetivação que pressupõe agência e empoderamento. (ZOLIN, 2018, p.4)

Nesse contexto, encontra-se o romance Desmundo ${ }^{1}$ (1996), de Ana Miranda, escritora brasileira com obras traduzidas para vários países e que coleciona diversos prêmios literários. O romance citado, objeto de estudo desse trabalho, trata da colonização do Brasil, conferindo

1 O romance foi adaptado para o cinema por Alain Fresnot, em 2002. 
destaque à vida de Oribela, uma entre as sete órfãs que são forçadas a deixar Portugal para habitar solo brasileiro. No texto, encontramos personagens que rompem com suas mais arraigadas referências e são lançadas ao desconhecido, estranho e sem referencial, ao exílio. Porém, é a partir da experiência exílica que Oribela (re)constrói, paulatinamente, a sua identidade, como veremos ao longo desse trabalho.

Antes mesmo de dar início à história, a partir da primeira epígrafe, a autora aponta um prenúncio de que o exílio se faz presente no romance. Por meio de uma citação do poeta português, Fernando Pessoa, anuncia "Ir para Longe, ir para Fora, para a Distância Abstrata / Indefinidamente, pelas noites misteriosas e fundas, / Levado, como a poeira, pelos ventos, pelos vendavais!" (PESSOA, Apud MIRANDA, 1996, p.5). É desse modo que Oribela é lançada ao Brasil, veio de longe, uma terra distante, e sua vida toma um rumo incerto, até então inimaginável para a jovem. Ela é retirada do orfanato em que vivia, conduzido por freiras, educada conforme os preceitos da igreja católica, tendo como companheiras meninas também órfãs, sem família para acolhimento. Junto às freiras, Oribela passa os dias em uma rotina sem grandes mudanças e sonha com um futuro idealizado, até ser levada para um lugar desconhecido. 
A segunda epígrafe da obra é um registro histórico. Trata-se de uma carta do padre Manoel da Nóbrega ao rei de Portugal, na qual deixa evidente a necessidade de mulheres brancas no país que se formava, e por isso, solicita a vinda delas.

A' El-Rei D. João

Jesus

Já que escrevi a Vossa Alteza a falta que nesta terra ha de mulheres, com quem os homens casem e vivam em serviço de Nosso Senhor, apartados dos pecados, em que agora vivem, mande Vossa Alteza muitas orphãs, e si não houver muitas, venham de mistura dellas e quaesquer, porque são tão desejadas as mulheres brancas cá, que quaesquer farão cá muito bem à terra, e ellas se ganharão, e os homens de cá apartar-se-hão do pecado. (NÓBREGA Apud MIRANDA, 1996, p.7)

As órfãs não tiveram escolhas, e sim foram escolhidas. Dessa forma, seus sonhos e vontades foram desconsiderados. Além do sofrimento de viver em um abrigo e da falta de uma família, receberam a punição de vir para o Brasil a contragosto, com casamentos arranjados. Cabe ressaltar que vir para o Brasil era uma forma de castigar aqueles que não eram bem-vindos na metrópole, portanto, para esta terra selvagem eram enviados os degredados: ladrões, mendigos, prostitutas, entre outros. 
Esse contexto contribui para a sensação de não pertencimento e o desejo de retornar à terra natal. Segundo Said (2003, p. 47),

O exílio nos compele estranhamente a pensar sobre ele, mas é terrível de experimentar. Ele é uma fratura incurável entre um ser humano e um lugar natal, entre o eu e seu verdadeiro lar: sua tristeza essencial jamais pode ser superada. [...] As realizações do exílio são permanentemente minadas pela perda de algo deixado para trás para sempre.

Aqui, cabe a distinção entre o exílio de outras formas de afastamento da terra natal. O exilado é aquele que está impedido de voltar à sua terra. Aqueles que "moram voluntariamente em outro país, geralmente por motivos pessoais ou sociais" (SAID, 2003, p.54), são os expatriados. Já os emigrados, segundo o autor, são aqueles que podem ou não ter escolhido abandonar seu país. O exílio, portanto, não é uma questão de escolha.

A questão de "pensar" sobre o exílio, de estar só, de perceber o fluir dos sentimentos, o possível amadurecimento fruto do sofrimento, o sentimento de saudade, o contato com novas leituras, fizeram com que grandes obras fossem criadas por autores em situação de separação da terra natal. O grau de conscientização política e cultural de muitos intelectuais os levam a tentar compreender e questionar 
sua própria condição. Nesse sentido, o exilado busca sempre algo para superar a dor da separação, e a literatura acaba sendo um subterfúgio, que, muitas vezes, resulta em obras de legítima qualidade.

No entanto, nem sempre essa é a saída para o exilado. $\mathrm{Na}$ época da colonização do Brasil, aqueles que vinham para a colônia sentiam uma ruptura abrupta em suas vidas, tendo em vista a diferença estrutural, tanto física quanto social, entre o país de origem e de destino. Até a chegada dos portugueses, as terras brasileiras eram habitadas somente pelos índios, que possuíam cultura e costumes particulares, muito diferentes das do homem branco, colonizador. Não havia, portanto, a organização social do europeu, o comércio, as igrejas, enfim, tudo seria construído considerando o aspecto do colonizador. Esse contexto contribui para que o exilado se sinta ainda mais desamparado, solitário, resistente à situação que se encontra. Segundo Said,

$$
\begin{aligned}
& \text { por mais que tenham êxito, os exilados } \\
& \text { são sempre excêntricos que sentem sua } \\
& \text { diferença (ao mesmo tempo que, com } \\
& \text { frequência, a exploram) como um tipo de } \\
& \text { orfandade [...] o exilado insiste ciosamente } \\
& \text { em seu direito de se recusar a pertencer a } \\
& \text { outro lugar. (2003, p.47) }
\end{aligned}
$$

As experiências vivenciadas no exílio são individuais e únicas, enquanto uns procuram se adaptar à nova realidade, 
outros se fecham procurando viver como se ainda estivessem no seu país de origem, em uma tentativa de manter-se no passado, preservar os costumes, em uma insistente posição de não pertencimento. Essa recusa de pertencimento está muito mais relacionada à manutenção das raízes, culturas, do que em relação à localização geográfica. A questão não é somente o lugar, mas o que ele representa ou não representa para o exilado. Assim sendo, "o exílio jamais se configura como o estado de estar satisfeito, plácido ou seguro. [...] é a vida levada fora da ordem habitual [...] assim que nos acostumamos a ela, sua força desestabilizadora entra em erupção novamente" (SAID, 2003, p.60). Nesses desencontros, o sujeito não consegue firmar uma identidade no local, pois na reafirmação de suas origens não se encaixa no novo contexto. Essa ideia é reforçada por Nouss (2016, p.60), quando afirma que "até prova em contrário, o lugar de exílio será sempre injusto e o exilado sentir-se-á um rebelde, com seus valores a absorver uma experiência sem mediação".

Outra questão importante a ser destacada éa solidariedade do exilado para com o seu grupo. Caso o exilado não esteja só, isto é, não seja o único a vivenciar a experiência de exílio, há um sentimento de companheirismo entre os pares. Planos 
são feitos em conjunto, e aquilo que será uma conquista é compartilhado com os semelhantes.

O exílio é uma condição ciumenta. O que você consegue é exatamente o que você não tem vontade de compartilhar, e é ao traçar linhas ao redor de seus companheiros que os aspectos menos atraentes de estar no exílio emergem: um sentimento exagerado de solidariedade de grupo e uma hostilidade exaltada em relação aos de fora do grupo, mesmo aqueles que podem, na verdade, estar na mesma situação que você. (SAID, 2003, p.51)

Destacamos ainda a questão do nacionalismo. Uma forma de ratificar a origem, de intensificar o sentimento de não pertença no local de exílio, é exaltando a pátria. Para isso, Said (2003, p.57) afirma que "deve-se também reconhecer que o nacionalismo defensivo dos exilados favorece amiúde a consciência de si mesmo tanto quanto as formas menos atraentes de autoafirmação". Dessa forma, o indivíduo vê-se deslocado, em conflito com o lugar em que habita, que não reconhece, com suas raízes fragmentadas. Por isso, exaltar o local de origem e reafirmar seu nacionalismo é uma maneira de ratificar sua origem, de ter um lugar no mundo. Said (2003, p.49) salienta, então, que "o nacionalismo é uma declaração de pertencer a um lugar, a um povo, a uma herança cultural. Ele afirma uma pátria por uma comunidade de língua, cultura e costumes $[\ldots]^{\prime \prime}$. 
A consciência exílica geralmente se apresenta no deslocamento do sujeito em relação à sua pátria, seja ele refugiado, expatriado etc., em busca de uma construção identitária. O filósofo Alexis Nouss tem se dedicado aos estudos da experiência migratória. Para melhor designar o sentimento daquele que está na condição do exílio, o pesquisador apresenta um neologismo a partir do sufixo -ance da língua francesa: "exiliance", traduzido em português como "exiliência", descrito por ele como

experiência exílica convoque o neologismo exiliencia que the acentua as potencialidades de afirmação ou resistência, pelas quais escapa ao exclusivo determinismo de factores externos. Não existe nenhuma passividade na exiliência, porquanto não é sinal nem de ausência nem de perda; pelo contrário, representa a afirmação de um ethos. Núcleo existencial comum a todas as experiências de sujeitos migrantes, quaisquer que sejam as épocas, as culturas e as circunstâncias que as acolhem ou que as provocam, a exiliência declina-se em condição e consciência, podendo inclusive acontecer que as duas, em graus distintos, não coincidam: pode alguém sentir-se em exílio sem ser concretamente um exilado (consciência sem condição), como pode alguém ser um exilado em concreto, sem contudo sentir-se em exílio (condição sem consciência). (NOUSS, 2016, p.53)

Assim, o estudioso afirma que a exiliência impera sobre a consciência do sujeito, independente do espaço geográfico 
em que se encontra. Dessa forma, pode se manifestar inclusive naquele que não esteja exilado de fato, mas que determinadas condições o leve a sentir como se estivesse. Segundo Lima (2017, p.16), “à maneira da 'différance' de Derrida, a 'exiliance' se apoia na indecisão entre atividade e passividade trazida pelo sufixo, a fim de sugerir que a experiência exílica possui uma dinâmica nem sempre contemplada pelos termos já existentes".

Apesar das dificuldades advindas da experiência exílica, esta pode contribuir para o processo de amadurecimento e (re)construção identitária do sujeito. As novas relações e experiências vivenciadas pelo exilado podem auxiliá-lo na busca pelo "eu" e na tentativa de (re)construir, paulatinamente, a sua própria identidade. Segundo Bauman (2005, p. 17),

\begin{abstract}
tornamo-nos conscientes de que o 'pertencimento' e a 'identidade' não têm a solidez de uma rocha, não são garantidos para toda a vida, são bastante negociáveis e revogáveis, e de que as decisões que o próprio indivíduo toma, os caminhos que percorre, a maneira como age [...] são fatores cruciais tanto para o 'pertencimento' quanto para a 'identidade'.
\end{abstract}

Diante disso, o pertencimento e a identidade não são elementos imutáveis da vida do sujeito, pelo contrário, são passíveis de modificação a partir de suas próprias 
vivências e decisões. A ideia de identidade compreende, portanto, "uma tarefa a ser realizada, e realizada vezes e vezes sem conta, e não de uma só tacada" (BAUMAN, 2005, p.18).

Stuart Hall (2006) aborda a questão da identidade na pósmodernidade, considerando que o conceito de sujeito e, portanto, de identidade, pode ser compreendido a partir de três concepções, quais sejam: do iluminismo, do sociológico e do pós-moderno. $O$ primeiro diz respeito ao sujeito centrado e unificado; o segundo forma-se na relação com outros sujeitos; e o terceiro é o sujeito fragmentado, constituído pela instabilidade e por diferentes identidades. A "fragmentação das identidades", processo abordado por Hall (2006, p.1213), "produz o sujeito pós-moderno, conceptualizado como não tendo uma identidade fixa, essencial ou permanente. A identidade torna-se uma 'celebração móvel'". Sob essa perspectiva, o sujeito já não é integral, estabilizado e unívoco, assumindo para si identidades, por vezes, até mesmo contraditórias.

Para o autor, a identidade apenas se completa com o auxílio do Outro - a alteridade, pois é por meio do contato com o outro que o "eu individual" existe. Bauman (2005) ratifica essa ideia quando salienta a importância dos vínculos na vida do sujeito para a constituição de sua identidade. 
Afinal de contas, a essência da identidade [...] não pode ser constituída senão por referência aos vínculos que conectam o eu a outras pessoas e ao pressuposto de que tais vínculos são fidedignos e gozam de estabilidade com o passar do tempo. Precisamos de relacionamentos, e de relacionamentos em que possamos servir para alguma coisa, relacionamentos aos quais possamos referir-nos no intuito de definirmos a nós mesmos. (p.74-75)

Se, como afirma Bauman (2005), a constituição da identidade se dá a partir do vínculo entre o "eu" e o "outro", das relações verdadeiras estabelecidas entre os sujeitos, é possível que a mulher passe pelo processo de subjetivação feminina(TOURAINE, 2007) por meio dos lações criados com outras pessoas.

esta vontade de subjetivação, de autoafirmação [sic] das mulheres, se transforma num dos melhores exemplos de uma concepção democrática centrada sobre a vontade de cada um de se afirmar como sujeito contra a lei imposta por outros ou contra as instituições centradas sobre o funcionamento e a integração do sistema social antes que sobre a consciência da liberdade. (p.53)

Nesse sentido, Touraine (2007) expõe que o desejo de subjetivação feminina se ergue contra as leis impostas pelo outro, isto é, pelo patriarcalismo. Este processo pode ocorrer, então, a partir do auxílio do Outro, que contribui para que 
a mulher vivencie a subjetivação feminina e se afirme enquanto agente de sua própria história, independentemente de regras ditadas por terceiros e/ou por instituições.

A seguir, procuramos fazer uma leitura da obra de Miranda, enfocando os aspectos teóricos discutidos até o presente momento.

\section{ENTRE CÁ E LÁ}

O romance Desmundo narra a trajetória de Oribela, uma das 7 jovens órfãs enviadas para o Brasil, em 1555, pela rainha de Portugal (a pedido de Pe. Manoel da Nóbrega), para se casarem com cristãos que habitam a colônia. A obra foi criada a partir de uma séria e profunda investigação historiográfica, comprovada pela referência bibliográfica encontrada no final do livro. $O$ texto, dividido em dez capítulos, é narrado em primeira pessoa por Oribela, que conta sua visão sobre a terra, o casamento forçado, além de seus traumas interiores. O desejo de regressar a Portugal não a abandona, e por esse propósito tenta fugir duas vezes do marido, mas é recuperada como um animal que escapa do cativeiro. Em uma das tentativas, abriga-se na casa do mouro Ximeno Dias, homem pelo qual se apaixona e com quem tem um filho.

Desde as primeiras páginas do livro, a protagonista demonstra o seu descontentamento em deixar sua terra natal, como se uma fenda acometesse sua alma. 
Cada dia me fizeram mais distante de onde eu fora arrancada com muita pena por serem meus pés quais umas abóboras nascidas no chão, minhas mãos uns galhos que se vão à terra e a agarram por baixo das pedras fundas. Aquele era o meu destino, não poder demandar de minha sorte, ser lançada por baías, golfos, ilhas até o fim do mundo. (MIRANDA, 1996, p.15)

Por uma linguagem bastante poética, o leitor se depara com o desgosto e a contrariedade da menina por estar fora de seu país. Fica evidente no discurso a condição de exílio, uma vez que não cabe a ela escolha, atravessou o oceano sem vontade própria, e não pode regressar por decisão pessoal. Pelas palavras de Oribela, percebemos que a menina teve seu vínculo com a metrópole partido, além de deixar claro sua rejeição ao local em que foi despejada, considerando o "fim do mundo".

Como característica própria do exílio, tanto Oribela quanto as demais órfãs pensavam sobre a situação instável, insegura, de medo pela qual passavam. Apesar de terem umas às outras, sabiam que essa situação não permaneceria assim, o destino era cada uma se juntar a um homem, aquele que faria a escolha de qual delas se apropriar e que elas deveriam aceitar como marido.

As mancebas, nenhuma de nós dormia de boca fechada, os ouvidos alongados, cada qual a pensar em seu coração que dias viriam, que ventos assoprariam, o que haveria 
ali, recolhidas ao pensamentos de nossa fortuna, ocupando-os no sentimento das coisas que nos mais doíam, numa quietação de pouco sono e medo das nossas próprias imaginações, as quais nos faziam desejar grandemente a chegada da manhã, porque tudo quanto podíamos estender aos olhos era a pequena ordem com que a desventura nos tinha cortado a vida. (MIRANDA, 1996, p.21)

No trecho citado, as jovens ainda não tinham desembarcado da nau que as trouxe à colônia, aguardavam o clarear do dia na embarcação, para então conhecer o local onde passariam o resto da vida. A incerteza do futuro é uma tortura para a jovem.

Outro sentimento experimentado por Oribela é a solidão. Sente falta do que ficou para trás, da rotina do convento, entre as irmãs e outras órfãs. Apesar do alívio de ter chegado, após uma longa viagem exaustiva, não se permite apreciar o que o novo mundo poderia oferecer, sempre o considerando indesejado; "as mãos fornicadoras de dona Bernardinha, a cruz, o Agnus Dei, as procissões a bordo, [...] tudo era passado, chegamos a um novo país com o coração em júbilo, mas de dúvida e receio, para povoar um despejado lugar" (MIRANDA, 1996, p.16).

Mais um ponto a ser destacado em relação à situação de exílio de Oribela é a necessidade de ratificar, com frequência, 
o não pertencimento à colônia e, em contrapartida, a reafirmação de sua nação, exaltação do nacionalismo, seu pertencimento a outro espaço. Quando se refere ao Novo Mundo, utiliza colocações como "tocar os pés ali naquela terra onde nunca entrava o inverno" (MIRANDA, 1996, p.13) ou ainda "mas eu pensava, se dera ele licença para daqui onde fui lançada ir ver a face de minha terra, crê que assim avoaria meu corpo a ir beijar aquele chão, como o esfaimado prisioneiro no primeiro ímpeto de sua soltura" (MIRANDA, 1996, p.83). Para mencionar Portugal, usa o pronome possessivo "minha" terra; já em relação ao Brasil, opta pelo demonstrativo "naquela", excluindo-se do local. Isso demonstra seu distanciamento de uma nação e sua aproximação de outra. Podemos afirmar que a personagem está passando pelo processo que Nous (2016) denomina exiliência: ela potencializa sua resistência, nesse caso, tendo a condição e a consciência do exílio. A exiliência é notada em várias falas da jovem, durante todo o percurso da narrativa. Mesmo quando se depara com outras mulheres da corte, transitando em seus melhores trajes, ela as renega, considerando que não são como as da corte:

Vinha com as mulheres de vestido leves [...] Mas não eram como as mulheres do reino, não tinham os cabelos clareados de açafrão nem os cílios arrancados, o rosto pintado 
gravados em si os pecados para desfigurar, desfeitas de sua natureza, tão pintadas. (MIRANDA, 1996, p.70)

Apesar de toda resistência de Oribela em aceitar o Brasil e a predestinação articulada por terceiros para sua vida, a força da jovem não foi suficiente para destituir o que estava tramado, assim, contra sua vontade, teve de se casar com Francisco de Albuquerque, desbravador da colônia, que a escolheu. Por se tratar da perspectiva feminina em relação ao período do Brasil Colonial, acompanhamos o sofrimento de Oribela por habitar uma sociedade extremamente machista e patriarcal. À mulher cabe o lugar de subalterna, que deve acatar as regras advindas do gênero oposto. Apesar da dominação masculina, que se ergue contra a protagonista, ela não desiste de buscar meios para fugir do local em que se encontra e do marido perverso, que a tem como objeto.

Mesmo depois de casada, de ter vivenciado várias desilusões no casamento, a jovem encontra forças para planejar e replanejar meios que a levasse de volta à terra natal. Após fuga frustrada na tentativa de retornar à Portugal, ela não desiste de traçar meta para conseguir se infiltrar em uma nau rumo à Europa.

Uma nau portuguesa fundeara na baía diante da cidade velha, mercante e de passageiros. Francisco de Albuquerque se tomou de 
receios em me perder de vista e as vigias eram de noite e de dia, com gente em revés, saindo o guarda da porta nas horas do banho quando vinha Francisco de Albuquerque em pessoa vigiar. Havia ainda no meu coração o desejo de tornar, embora fosse a cada anoitecer mais pálida a vista da Princesa [...] E tanto me agarrava eu, como se fosse um fio de seda que levasse ao mundo, estando eu no desmundo. (MIRANDA, 1996, p.138)

Tanto o desejo de retorno à metrópole quanto a ideia do Brasil como desmundo é constante no pensamento da jovem, o sentimento de exílio é permanente enquanto ela se encontra fora da sua nação. A situação de prisioneira, incessantemente vigiada, tanto pelo marido quanto por seus capangas, de certa forma desaponta Oribela quanto a execução do plano de retorno. Quando utiliza a expressão "havia ainda [...] desejo de retornar", é possível compreender que a jovem sente que a vontade de regressar pode ser sucumbida.

Ela faz planos em silêncio, busca uma saída, como um fugitivo. O meio de transporte para sua terra está a passos, mas ela não consegue embarcar.

O ranger se ouvia e fez frio dentro de mim. Trouxera com ela, suas velas, seus ventos, um gosto na boca, de fugir. Busquei com os olhares aquele que poderia me dar passagem para a nau, mas de temor me tomei, entre 
aqueles cossairos, só se fora uma protegida do padre, mas que padre daria asas a uma esposa fugir de seu matrimônio? (MIRANDA, 1996, p.150)

Pelo trecho percebemos que Oribela vive um duplo conflito, pois não pode voltar para a metrópole e tampouco consegue se libertar das garras do marido.

A ânsia de recusa ao espaço em que se encontra faz com que Oribela não encontre beleza alguma na América. Cita a praia e o mar sem contemplação, e quando se volta à construção das igrejas que se formam, faz críticas contundentes, destaca o que há de rudimentar. Coloca em dúvida, inclusive, a presença de Deus no espaço que, para ela, não está à altura d'Ele. A jovem acentua a ideia de esses templos religiosos estarem muito aquém daqueles com o mesmo propósito, em civilizações mais desenvolvidas, além de, frequentemente, se referir à colônia como "fim de mundo", lugar inabitável.

Admiradas em avistar um terreiro debruçado sobre o mar e de artilharia muito grossa assentada, uma igreja que se fazia e the floresciam naves sobre pilares lavrados, esguios em arrojo, capelas nos topos ainda sem torres nem sinos, como que sustentada de estrela, querendo se como qualquer outra em tal ou qual reino da terra, que era onde iria morar Deus se chegasse a este fim de mundo e parecer catedral. (MIRANDA, 1996, p.35) 
A condição de estar em um país indesejado, com a ideia fixa de retorno ao seu país, faz com que Oribela enfrente vários conflitos internos. O casamento forçado privou-a dos privilégios da juventude, dos sonhos em se casar com um jovem idealizado, "príncipe encantado", fazendo-a se deparar com o lado negativo da existência, as frustrações, os desencantos.

Nesses momentos de desalento, o companheirismo daqueles que estão na mesma situação do exilado faz aflorar as esperanças. Há, portanto, um enorme sentimento de solidariedade para com o seu semelhante enquanto o inverso acontece com aquele que está fora do grupo.

Disse querer ir embora deste país e tornar ao seu. Nós vamos partir daqui, dona Bernardinha, juntas. Como? Não sei. A fingir de homem, em roupas e chapéu, botas. Com as primeiras bafugens da monção. Tu consegues as moedas e eu as passagens, que nós podemos insinuar numa das naus dessa corja e feito homens vão nos respeitar e embarcamos e tornamos. (MIRANDA, 1996, p.152)

Oribela, jovem bonita e valente, ao planejar a fuga vestida de homem, busca a descorporificação. Afastar-se da condição feminina é um meio de infiltrar-se em um mundo dominado pela lei do mais forte, em que predomina a força exercida pelo homem e a consequente opressão feminina.

A viagem tanto externa quanto interna de Oribela contribuiu para seu amadurecimento. A mãe morreu durante 
seu parto e o pai, nos primeiros anos, assumiu a filha, mas a contragosto. Embriagava-se com frequência e deixava que a filha percebesse que não era querida por ele. A menina passa, então, a viver no orfanato, e a vida junto às freiras foi um período de maior tranquilidade para a garota, mas interrompido com sua vinda à colônia. A partir da chegada ao Brasil, começa um intenso processo de amadurecimento. A jovem não aceita a condição imposta à sua vida pela corte, de assumir o papel de esposa, em um sistema estritamente patriarcal, em que a mulher não tem voz nem vez. No entanto, Oribela se porta de modo diferente do esperado. No momento de apresentação ao pretendente, ela se rebela: "Disse o padre ser eu pura e virgem donzela de mosteiro de freiras [...] Reparasse o homem na formosura de minha feição, na suavidade mulheril e esquecesse da rebeldia [...] O homem me veio mirar e no rosto lhe cuspi" (MIRANDA, 1996, p.56). A partir desse ato, Oribela passa a buscar por aquilo que entende ser melhor para sua vida. Desse ponto em diante da narrativa, uma sucessão de encontros e desencontros contribuirão para que a menina se transforme em mulher e (re)construa a sua identidade.

Durante o período de ausência de Francisco de Albuquerque, Oribela consegue viver livremente. A principal responsável pela libertação e autoconhecimento 
da protagonista é Temericô, uma das índias que trabalhava na casa do patrão. Apesar do choque cultural inicial, com o passar do tempo, a jovem demonstra grande estima pela índia, sua companheira diária.

Nesse tempo se deu minha amizade se encantar por uma natural, de cor muito baça, bons dentes brancos [...]. Vinha sempre ela ter a mim com o prato de comida no mais colhia figos que assava na fogueira e trazia frutas, mel e me tratava os cabelos untados com óleo de cocos-bravos e foi quem me curava os ferimentos dos pés. (MIRANDA, 1996, p.119)

Com o passar dos dias, Oribela percebe que pode confiar em Temericô. A índia dispensava à órfã todos os cuidados necessários para que ela se sentisse confortável e menos infeliz. A partir da amizade entre elas, a jovem consegue se sentir livre e disposta a reconstituir a sua identidade e conhecer melhor a si mesma.

Tinha feitas para mim umas ervas de acalmar, de beber a fumaça. Aprendi os fumos de naturais, que me deixavam pasmada e sonhadora, sem ver o correr dos dias, o parar das noites, quando na minha fantasia eu procurava o que não queria achar. [...] Aprendi a me desnudar, no quarto, após o banho, que havia um frescor sobre a pele e se entranhando nela, uma luva de vento, um véu de seda fria, que a roupagem abafava e incendiava. E ria ela. E ria. Bom era viver numa casa sem homem a ordenar. (MIRANDA, 1996, p.126) 
Oribela e Temericô conversavam sobre as culturas das quais faziam parte e compartilhavam segredos. A partir da relação estabelecida entre a jovem e a índia, Oribela tem a primeira oportunidade de se reconhecer enquanto mulher e conhecer o próprio corpo. Agora, ela se desnudava após o banho e descobria o frescor sobre a pele. Vemos que o pertencimento e a identidade de Oribela são construídos por meio das decisões e caminhos que ela toma e, nesse sentido, a decisão de adentrar outra cultura através de Temericô é fundamental para isso. Ao conhecer o outro, a personagem descobre a si mesma e se permite vivenciar experiências significativas para a (re)construção de sua identidade. Finalmente, a personagem percebe como era bom viver em uma casa sem as ordens de um homem. Quase como um momento de epifania, a órfã vai descobrindo, paulatinamente, quem é e quem pode se tornar, o que a leva a tomar dimensão de sua existência.

Outro contato fundamental para a (re)construção identitária de Oribela é o encontro com Ximeno Dias. Mais uma vez acontece o choque cultural, pois a órfã, criada em um monastério português, era incapaz de aceitar sua paixão por um muçulmano. No entanto, quem the concede abrigo em uma das vezes que foge do marido, é o muçulmano. Ximeno Dias se mostra leal à órfã, e suas atitudes a cativam: 


\begin{abstract}
Vos sou leal, senhora, como sempre serei assim nesta terra como nas outras, antes ficasse cego que me tirasse de suas vistas, antes lhe caísse a cabeça a me ser infiel [...] para certificar sua doce amizade e esmaltar minha alma com seu sangue. Tudo faria por mim em minha suavidade mulheril. Muito provou o Ximeno sua fala, tendo a mim naquela alcova sem nenhum destrato ou requerimento, uma tão boa apuração que me fazia um vazio no peito quando não estava ele perto. Tanto que atinei poder estar sendo encantada pelo feiticeiro. (MIRANDA, 1996, p.175)
\end{abstract}

Diante das palavras do mouro, de seu carinho e cuidado para com Oribela, ela começa a gostar verdadeiramente dele, haja vista que ele era em tudo o oposto de seu marido. Então, guiada por seus desejos, relaciona-se com Ximeno Dias, permite-se viver os prazeres do corpo e estar na presença de um homem que a queria bem.

Mas assim o vi. Era tal que atraiu em tudo que há em mim e lhe fui sentir a boca, ele despertou e me tomou em seus braços num desatino e grandíssimo ímpeto, correndo com as mãos pelo meu corpo, dizendo falas de amante, a beijar meus beiços [...] a mim dava um gosto bom, fino punhal frio arrastando em toda minha pele, a querer sentir que ele se fazia em mim. (MIRANDA, 1996, p.179)

Apesar da forte religiosidade da menina, mesmo casada sob a bênção da igreja católica, ela não se curva 
a seu dominante, o marido Francisco de Albuquerque. Percebemos como a protagonista assume para si diferentes identidades ao longo da narrativa: durante o tempo vivido no convento, tem de seguir os preceitos da igreja católica; ao chegar em Portugal, torna-se resistência frente a uma sociedade patriarcal; por meio das relações estabelecidas com Temericô e Ximeno, permite ser aquilo que deseja, sem medo de qualquer retaliação ou castigo. Assim, a sua identidade torna-se o que Hall (2006) chama de "celebração móvel", afinal, Oribela já não possui uma identidade fixa, estável, mas assume identidades até mesmo contraditórias. Contudo, o trajeto percorrido auxilia a jovem no processo de (re)construção identitária, uma vez que as experiências vivenciadas foram de fundamental importância para que a personagem pudesse conhecer melhor a si e a quem, de fato, estava se tornando.

A partir dos laços criados, a protagonista passa, então, pelo processo de subjetivação feminina de que fala Touraine (2007), pois Oribela se dá o direito de conhecer o outro e, nesse processo, de conhecer a si mesma e a quem havia se tornado. Sendo assim, a amizade com Temericô e as demais índias e o relacionamento amoroso que vive com Ximeno Dias permitem à jovem ser protagonista e agente de sua própria história. 
Os laços e vínculos afetivos construídos cooperam, sobretudo, para a firmação de uma identidade que permite à órfã se libertar das amarras que a prendiam.

É por meio do outro que a jovem constrói a si mesma, são os relacionamentos que oferecem a ela a possibilidade de conhecer o que até o momento era desconhecido. Sem medo ou culpa, Oribela constitui a sua identidade, longe de toda forma de submissão e dominação masculina.

Por fim, a protagonista descobre-se grávida e, dias após o nascimento da criança, o esposo reconhece que o filho é do mouro, Ximeno Dias. Então, Francisco de Albuquerque foge com o recém-nascido, e a sua esposa ateia fogo na casa a fim de destruir e apagar tudo o que vivera ali. Sem saber se está delirando ou não, a mãe ouve o choro de seu filho e o mouro aparece com a criança no colo.

Temos um desfecho aberto, que não permite afirmarmos com total certeza se a protagonista conseguiu recuperar a criança e, além disso, estar ao lado de seu companheiro, novamente. Independente disso, podemos afirmar que o fato de gerar um filho também contribui para construir outro aspecto identitário de Oribela, afinal, ela se torna mãe. Além disso, ter um filho como fruto do amor existente entre a jovem e o mouro configura-se em um gesto de resistência da órfã. Gerar um filho fora do casamento é um fator agravante 
para a moça, sobretudo ao se tratar do século XVI, porém, a personagem, destemida e dona de si decide dar vida à criança. Portanto, aqui, o corpo atua como

espaço simbólico da luta e da resistência, descontruído e deseducado, que rejeita a escolarização tradicional opressora, as normas de gênero naturalizadas consideradas "normais" e se reconstrói como um espaço de afeto, empoderamento e emancipação que rompe o silêncio. (LOUSA, 2017, p.178)

A órfã faz suas escolhas e enfrenta os desafios para conquistar o que deseja. Esse caminho percorrido, desde a chegada em terras estrangeiras, desconhecidas e diferentes do seu reino, o estado e sentimento de exílio, o contato com a natural, a experiência amorosa com o mouro, o nascimento do filho, dentre outras experiências vividas, desencadeiam um processo de formação, transformando a menina em mulher, não sendo mais possível voltar a ter a vida em orfanato.

\section{CONSIDERAÇÕES FINAIS}

Em Desmundo, Ana Miranda apresenta aspectos da condição de mulher na época da colonização do Brasil. Temos o grito de voz do oprimido, pela personagem Oribela, menina que, desde o início, apresenta um caráter rebelde e determinado. Por ter vindo à força para o Brasil, mantém forte recusa a esse país e intensa vontade de retornar à metrópole, sofrendo com a condição de exílio. Outro aspecto considerável é o processo de (re)construção identitária 
da protagonista, desencadeada por vários motivos, como os conflitos vividos pelo exílio, convivência com outros tipos de cultura, a amizade e troca de experiências com as naturais, culminado na paixão sentida pelo mouro, Ximeno Dias. Dessa maneira,

a literatura de mulheres, historicamente marginalizada, vem ganhando espaço e veiculando uma voz dissonante [...] sobretudo no que se refere a representações de identidades femininas que, em boa escala, já podem ser consideradas representativas do conjunto das diversas perspectivas sociais das mulheres. E se ainda não é capaz de lhes retratar plenamente a diversidade identitária, certamente avança um bom tanto em relação à literatura hegemônica. (ZOLIN, 2010, p.194)

Assim, por trás da tessitura do romance, temos uma protagonista que caminha rumo à aprendizagem, e que, apesar do exílio, encontra meios de fazer valer os seus ideais, contrariando as expectativas que a sociedade da época tinha em relação à mulher. Nesse sentido, o texto escrito por Miranda representa um desnudamento da alteridade feminina, que discursa a partir da personagem Oribela. Essa personagem feminina, mesmo abalada após várias derrotas, não se dá por vencida e continua em busca de seus objetivos.

O desfecho da obra, de certa forma ratifica o que Said afirma sobre o exílio, "uma fratura incurável entre um ser humano e um 
lugar natal, entre o eu e seu verdadeiro lar: sua tristeza essencial jamais pode ser superada" (SAID, 2003, p.47), considerando que a história se encerra sem que Oribela se integre ao contexto brasileiro. O final aberto, nos permite inferir que pelo devaneio, a personagem traça uma possível meta a ser alcançada, em busca da família pretendida, recuperando o filho e o homem amado, ou a real recuperação de ambos. Ainda que não haja a confirmação de que a personagem abandonou o desejo de retorno à metrópole, ela não aceita o destino que lhe é imposto, se permite viver outras experiências, conhecer o Outro, e se livrar da dominação masculina que teve de enfrentar em solo brasileiro. Apesar de todos os percalços vividos, consegue se rebelar contra o sistema patriarcal da época e subverter as relações de poder entre gêneros.

\section{REFERÊNCIAS:}

BAUMAN, Zygmunt (2005). Identidade. Carlos Alberto Medeiros (Trad.). Rio de Janeiro: Jorge Zahar Editor.

HALL, Stuart (2006). A identidade cultural na pós-modernidade. Tomaz Tadeu da Silva e Guaracira Lopes Louro (Trad.). 11.ed. Rio de Janeiro: DP\&A.

LIMA, Renata Ribeiro (2017). "O papel do exílio na configuração do nacionalismo de Gonçalves Dias". Scripta, Belo Horizonte, 21(42), 1434. In http://periodicos.pucminas.br/index.php/scripta/article/view/ P.23583428.2017v21n42p14/12392. Acesso em 20.Out.2018.

LOUSA, Pilar Lago (2017). "Corpo como resistência: questões de gênero em poemas de Elizandra Souza". Letras Escreve, Macapá, 7(4), 159-180. In https://periodicos.unifap.br/index.php/letras/article/view/3066. Acesso em 20.Out. 2018. 
MIRANDA, Ana Maria Nóbrega (1996). Desmundo. São Paulo: Companhia das Letras.

NOUSS, Alexis (2016). Pensar o exílio e a migração hoje. Ana Paula Coutinho Mendes (Trad.). Porto: Afrontamento.

SAID, Edward (2001). "Reflexões sobre o exílio". In: Reflexões sobre o exílio e outros ensaios. São Paulo: Companhia das Letras, p.46-60. TOURAINE, Alain (2007). O mundo das mulheres. Francisco Morás (Trad.). Petrópolis, RJ: Editora Vozes.

ZOLIN, Lúcia Osana (2010). "Questões de gênero e representação na contemporaneidade". Letras, Santa Maria, 20(41), 183-195, jul./dez. In https://periodicos.ufsm.br/letras/article/view/12166. Acesso em 10.Out.2018.

(2018). "Estratégias de subjetificação na ficção contemporânea de mulheres: exílio, migração, errância e outros deslocamentos". Acta Scientiarum, Maringá, 40(2), 1-9, jul./dez. In http://periodicos.uem. br/ojs/index.php/ActaSciLangCult/article/view/41656/pdf. Acesso em 7.Nov.2018.

leda Maria Sorgi Pinhaz Elias é Doutoranda em Letras, com ênfase em Estudos Literários (UEM) e Mestre em Letras (UEM). É docente da Educação Básica (SEED/PR). Sua produção mais relevante é intitulada "A narrativa de Odette de Barros Mott e a formação do subsistema juvenil na literatura brasileira". É vinculada ao grupo de pesquisa CRELIT (Crítica e Recepção Literária). E-mail: iedapinhaz@gmail.com

Cíntia Roberto Marson é Mestranda em Letras, com ênfase em Estudos Literários (UEM). Graduação em Letras - Português/Inglês e suas respectivas Literaturas (UENP/CCP). E-mail: cintia.marson@hotmail.com 